\title{
Economic and Higher Education Partnership of Hungary and Kazakhstan
}

\author{
KINGA MAGDOLNA MANDEL \\ Affiliation: Eötvös Loránd University \\ Faculty of Education and Psychology, Budapest, Hungary \\ Email: mandel.kinga@ppk.elte.hu \\ ANARGUL BELGIBAYEVA \\ Affiliation: Sh. Ualikhanov Kokshetau State University \\ Business Department, Kokshetau, Kazakhstan \\ Email: anargul.belgibayeva@mail.ru
}

\begin{abstract}
The aim of our research was to describe, compare, and analyze the development of business and educational co-operation between Kazakhstan and Hungary over the past 19 years. The research was prompted by the university-level co-operation between the two countries that started in 2018, which was made possible by the strategic partnership that is the topic of the present article. We started from the hypothesis that both business and educational co-operation has developed linearly and significantly during the last 19 years. Our research methodology was based on gathering and analyzing secondary macroeconomic, trade, and educational co-operation data in the period between 2011 and 2020. The data were obtained from publications, national offices (statistical, commerce, and education), and international bodies (like Tempus Public Foundation, Eurostat, International Monetary Fund [IMF], and the World Bank). In this paper, we intend to link the main political, social, and macroeconomic endowments with business and educational developments of partnership in the two countries, trying to map out prospects for co-operation. One conclusion is that, although in the political communications of the two countries we were able to identify significant governmental efforts on both sides to support and enforce economic and educational co-operation, the data indicate a decrease in the size of business investments. At the same time, however, the educational co-operation between the two parties continues to develop further.
\end{abstract}

Keywords: economic partnership, higher education co-operation, international co-operation, Hungary, Kazakhstan 


\section{Introduction}

The co-operation between the two countries has been dated to 1992 when Hungary was among the first countries to recognize Kazakhstan's independence (Hungary, Kazakhstan 'strategic partners,' 2020). Since then, the relationship between the two countries has developed to the level of strategic partnership: Kazakhstan is Hungary's principal political and economic partner in the Asian region, while Hungary is Kazakhstan's most important partner in Central and Eastern Europe (Hungary, Kazakhstan 'strategic partners,' 2020).

We could only track just a couple of articles regarding the ties between the two countries. One of these is a cultural-anthropological and genetic study evaluating the common background shared by the Hungarians (Magyars) in Hungary and the Madjar population in Kazakhstan (Bíró et al., 2009). Another study analyzed the two-level game of Visegrád countries and Kazakhstan. It stated, that the EU's member states, among them the Visegrád ones (Hungary being one of them), focus on developing trade and economic relations with Kazakhstan, without entering into the sensitive issues of democracy promotion and human rights. Those are left for the EU's institutions to deal with (Plenta, 2016).

Other than these, there are the political declarations issued by the two governments, the annual Doing Business reports published by the World Bank (2020a, 2020b), the Trading Economics (2020a, 2020b, 2020c, 2021a, 2021b) statistics for the two countries, and a World Bank study on the privatization of the energy and natural gas industries in Hungary and Kazakhstan (World Bank, 1999). So far, we have not come across any study analyzing the international business and educational cooperation between the two countries. We aimed to fill this gap as far as possible with the available data, focusing on the development of co-operation in the past 18 years in terms of business and educational partnerships, to find answers to the following questions: How has business partnership evolved over the last 18 years? Has foreign direct investment (FDI) in the other country increased on the part of either country during the investigated period? Have examples of educational cooperation increased between institutions of (higher) education? Have student and teacher exchanges increased in the last 19 years?

\section{Methodology}

We used the comparative research method to evaluate the development of cooperation. At the same time, we tried to consider its limitations, as suggested by Azarian (2011), such as overgeneralization and the predominance of description over analysis. In using multiple, dual cases and comparative analytical strategies researchers are motivated by one or more reasons, typically related to either knowledge acquisition or accountability (Greene, 2000). In our case, the dominant motivation was knowledge acquisition. 
We aimed to gather and analyze all the possible available data on the development of economic trade and educational relationships between the two countries. Data were, therefore, gathered from many different bodies and organizations:

- international (for example, the World Bank, International Monetary Fund, the Tempus Public Foundation) and

- national ones (Hungarian Statistical Office [KSH], the Hungarian Chamber of Trade and Industry [MKIK], the Hungarian Consulate in Kazakhstan, the Hungarian affiliation of the Tempus Public Foundation [TPF], the Hungarian Educational Authority $[\mathrm{OH}])$.

Furthermore, we used data from available international studies and publications, for example, articles from The Budapest Times and Hungary Today.

We measured the extent of the economic cooperation using, on the one hand, the countries' basic macroeconomic data, like exports and FDI investments. On the other hand, we examined the scope of educational cooperation through the number of scholarships and the number of exchange students and teachers. One main challenge that emerged was to find data on the development, size, and extent of educational cooperation. According to Arunachalam et al., it would also be possible to measure educational cooperation by assessing co-authorship of scientific papers (2000). However, we were unable to find the respective data. A limitation is that we approached and analyzed the relationships focusing more on the international and Hungarian sources-data and studies-rather than on Kazakh ones because of the former ones are easier and more open to access and because of their availability.

In the present article, we begin by describing the historical, political, and social context that has determined the countries' business and educational relationships. We, then, target the macroeconomic context, which sets the base for the foreign trade specificities of the two countries, before analyzing their economic cooperation, that is, trade exchange. Then we look at the R\&D sectors and that of the higher educational co-operation (exchange programs). Finally, we draw conclusions and outline prospects.

\section{Historical background}

There are close historical ties between Hungary and Kazakhstan. In the first half of the $13^{\text {th }}$ century, the Kipchak tribes migrated into Europe from the Kazakh steppe; their descendants live on the territory of modern-day central and eastern Hungary 
(Hungary, Kazakhstan 'strategic partners,' 2020). Similarly, some members of the Madjar ethnic group (of Hungarian origin) still live in the Torgay region of Kazakhstan. They are known in Hungary as relatives of the Hungarians. The similarities between the names "Madjars" and "Magyars" raise the question of genetic kinship between the Hungarians of today and the Madjars of Kazakhstan (Benkő, 2007).

The "Kurultaj" tribal assembly of the Hun nations is the biggest event in the world celebrating ancient Hungarian traditions, and it attracts more than a hundred traditional Hungarian organizations and non-governmental organizations from the Carpathian Basin. The first modern-day Kurultaj with Hungarian participation was held in 2007 in Saga, Kazakhstan. During this ceremony, the Madjars of Kazakhstan celebrated their existence and kinship with the Hungarian people (MKIK, 2020). This kinship has been confirmed by Bíró et al. (2009). They stated that there could have been genetic contact between the ancestors of the Madjars and the Magyars (Hungarians). Modern Hungarians may be able to trace their ancestry back to Central Asia, rather than to the eastern Uralic region, as other sources indicated (Bíró et al, 2009).

\section{Political background}

Both Hungary and Kazakhstan experienced political, economic, and cultural influences of the Soviet Union, although in different ways and forms. Hungary regained its sovereignty when the last troops left Hungary in 1991 (Székely, 2016) and is now a democratic parliamentary republic with a one-chamber parliament. Kazakhstan became independent in 1992, and it is a presidential republic with a two-chamber parliament (Tar \& Újvári, 2019).

In March 1992, Hungary opened its first embassy in Kazakhstan. A year later, in 1993, Kazakhstan likewise opened an embassy in Hungary (MKIK, 2020), the first one in Central and Eastern Europe (Hungary, Kazakhstan 'strategic partners,' 2020).

Meetings between representatives of the two countries have taken place almost annually since 1992-1993. One of the last such occasion happened on December 6, 2019, when the Kazakh ambassador Zhanibek Abdrashov presented his credentials to the Hungarian President János Áder (Hungary, Kazakhstan 'strategic partners,' 2020).

In July 2007, the European Union approved the EU and Central Asia: Strategy for a New Partnership, intending to intensify cooperation with the region (Plenta, 2016). In 2008, the Hungarian government formalized cooperation between the two countries by issuing Government Decree 197/2008 (August 4) on the Adoption and 
Promulgation of the Agreement on Economic Cooperation between the Government of the Republic of Hungary and the Government of the Republic of Kazakhstan ("A Kormány 197/2008. rendelete a Magyar Köztársaság Kormánya és a Kazah Köztársaság Kormánya között...," 2008).

The presidential visits made to Hungary by the first president of Kazakhstan, Nursultan Nazarbayev, in 1994 and 2007, as well as the visits made to Kazakhstan by the Hungarian presidents Árpád Göncz in 1997 and Pál Schmitt in 2010, added to the development of cooperation. In April 2019, the Hungarian prime minister Viktor Orbán also accorded an official visit to Kazakhstan, meeting President KassymJomart Tokayev, Prime Minister Askar Mamin, and Nursultan Nazarbayev (Hungary, Kazakhstan 'strategic partners,' 2020).

Based on the political ties outlined above, the activities of the Strategic Council, intergovernmental committees on trade, economic, and legal cooperation, as well as interparliamentary friendship groups contribute to the deepening of interactions between the two countries (Hungary, Kazakhstan 'strategic partners,' 2020). In view of the dynamically developing political and economic cooperation with the Central Asian region-that is, the member countries of the Turkic Council-the activities of the MKIK were expanded by the establishment of the Hungarian-Kazakh Section in 2012, which was renamed the Committee for Central Asian Relations on May 4, 2020. The Hungarian-Kazakh Business Council operates within the framework of this committee, which comprises the current member companies as well as the business councils to be established with the countries of the region in the future (MKIK, 2020).

\section{Social background}

Both countries have a multiethnic population. In Kazakhstan, the estimated population in 2020 was 19,091,949, with an annual population growth of 0.89\%. According to 2019 estimates, the population was made up of Kazakh (68\%), Russian (19.3\%), Uzbek (3.2\%), Ukrainian (1.5\%), Uighur (1.4\%), Tatar (1.1\%), German (1\%), and other (4.4\%) nationalities (MKIK, 2020). In Hungary, according to the National Statistical Office, the population was 9,769,526 in 2020-with an annual population decrease of $1.7 \%$ (KSH, 2020). According to Bátorfy (2019), in 2011 6.5\% of the population, 644,524 persons stated that they belonged to one of the 13 officially acknowledged nationalities in Hungary -which include German, Romanian, Slovakian, Croatian, Serbian, Ukrainian, Slovenian, and Roma-this proportion is estimated to be as high as $10 \%$ though. 
Kazakhstan is a secular state in which more than 40 faiths coexist in peace. The main religion is Islam (World Bank Group, 2020b). In 2020, the population included Muslims (70.2\%), Christians (26.2\%, comprising Russian Orthodox [23.9\%] and other Christians [2.3\%]), Buddhists (0.1\%), other denominations (0.2\%), and atheists (2.8\%) (MKIK, 2020). Hungary is also a secular state. According to the 2011 census, $39 \%$ of the population were Catholic (of these 37.2\% Western Catholic and 1.8\% Eastern Catholic), 13.8\% were Protestants (of these $11.6 \%$ Calvinist and $2.2 \%$ Lutheran), $1.9 \%$ belonged to other denominations, $18.2 \%$ had no religion, and $27.2 \%$ refused to answer the question (KSH, 2014).

\section{Macroeconomic background}

The territory of Kazakhstan is 2,724,900 square kilometers, almost thirty times the size of Hungary at 93,030 square kilometers (MKIK, 2020). The strategic goal of Kazakhstan is to take advantage of the global achievements of the Fourth Industrial Revolution; increase the efficiency of mineral extraction; prioritize energy efficiency and energy saving; and increase the share of renewable energies (Tar \& Újvári, 2019). Hungary's future vision is to become by 2030 the economic and intellectual capital of Central and Eastern Europe, with a highly competitive economy that provides secure livelihoods for its population and that is based on the sustainable utilization of its resources. Hungary is aiming at an increasing population, strong communities, a better quality of life, and an improved environment ("Nemzeti Fejlesztés 2030," 2014).

In 2020 the rate of sales tax in Kazakhstan is $12 \%$, the corporate tax rate is $20 \%$, the personal income tax rate is $10 \%$ and the dividend income received from a Kazakhstan source is taxable at $5 \%$, and $10 \%$ applies to all foreign-sourced dividend income (PWC, 2021a; Trading Economics, 2021a). The rate of sales tax in Hungary is $27 \%$, corporate tax is $9 \%$, the personal income tax is $15 \%$, the dividend income is taxable at $15 \%$, and an additional $15.5 \%$ social tax is payable on dividend income in certain conditions (PWC, 2021b; Trading Economics, 2021b). This indicates a greater emphasis on sales in Kazakhstan than in Hungary, the tax rate in Kazakhstan being less than half of that of Hungary. The personal income tax is also lower in Kazakhstan than in Hungary; however, the dividend tax is significantly higher in Hungary than in Kazakhstan, and there are higher corporate taxes in Kazakhstan than in Hungary.

On the World Bank's Doing Business portal, Kazakhstan ranks $25^{\text {th }}$ with a score of 79.6, and Hungary ranks 52 ${ }^{\text {nd }}$ with a score of 73.4, which means that, according to the World Bank data, it is easier to do business in Kazakhstan than in Hungary. 
Similarly, in terms of starting up a business, Kazakhstan ranks 22 ${ }^{\text {nd }}$; whereas Hungary ranks $87^{\text {th }}$ out of 100 , meaning that it is far easier to start up a business in Kazakhstan than in Hungary (World Bank Group, 2020a, 2020b).

\section{Table 1}

Main Economic Indicators in Kazakhstan and Hungary (2011-2019)

\begin{tabular}{|c|c|c|c|c|c|c|c|c|c|}
\hline & 2011 & 2012 & 2013 & 2014 & 2015 & 2016 & 2017 & 2018 & 2019 \\
\hline $\begin{array}{l}\text { KZ GDP per } \\
\text { capita (mil- } \\
\text { lion USD)* }\end{array}$ & 11,634 & $12,386.7$ & $13,890.63$ & $12,807.26$ & $10,510.77$ & $7,714,842$ & $9,247.581$ & $9,812.601$ & $9,731.145$ \\
\hline $\begin{array}{l}\text { HU GDP per } \\
\text { capita (mil- } \\
\text { lion USD)* }\end{array}$ & $14,150.97$ & $12,918.25$ & $13,687.25$ & $14,246.11$ & $12,651.57$ & $12,992.38$ & $14,457.61$ & $16,150.77$ & $16,475.74$ \\
\hline $\begin{array}{l}\text { KZ GNI per } \\
\text { capita (mil- } \\
\text { lion USD)* }\end{array}$ & 8,280 & 9,940 & 11,840 & 12,080 & 11,380 & 8,770 & 8,040 & 8,070 & 8,810 \\
\hline $\begin{array}{l}\text { HU GNI per } \\
\text { capita (mil- } \\
\text { lion USD)* }\end{array}$ & 13,170 & 12,990 & 13,480 & 13,540 & 13,220 & 13,050 & 13,080 & 14,760 & 16,140 \\
\hline $\begin{array}{l}\text { KZ GDP } \\
\text { annual } \\
\text { growth }(\%)^{\star}\end{array}$ & 7.4 & 4.8 & 6 & 4.2 & 1.2 & 1.1 & 4.1 & 4.1 & 4.5 \\
\hline $\begin{array}{l}\text { HU GDP } \\
\text { annual } \\
\text { growth }(\%)^{*}\end{array}$ & 1.8 & -1.5 & 1.9 & 4.2 & 3.8 & 2.2 & 4.3 & 5.1 & 4.9 \\
\hline $\begin{array}{l}\text { KZ industrial } \\
\text { annual } \\
\text { growth \%* }\end{array}$ & 3.47 & 1.89 & 3.12 & 1.75 & 0.10 & 1.71 & 6.30 & 4.45 & 6.31 \\
\hline $\begin{array}{l}\text { HU industrial } \\
\text { annual } \\
\text { growth \%* }\end{array}$ & -0.06 & -2.16 & -1.21 & 6.55 & 7.69 & -0.43 & 5.26 & 2.97 & 7.53 \\
\hline $\begin{array}{l}\text { KZ annual } \\
\text { price infla- } \\
\text { tion (\%)* }\end{array}$ & & 5.09 & 5.84 & 6.70 & 6.66 & 14.54 & 7.44 & 6.01 & 5.24 \\
\hline $\begin{array}{l}\text { HU annual } \\
\text { price infla- } \\
\text { tion }(\%)^{\star}\end{array}$ & 3.92 & 5.65 & 1.73 & -0.22 & -0.06 & 0.39 & 2.34 & 2.85 & 3.33 \\
\hline $\begin{array}{l}\text { KZ exports } \\
\text { of goods } \\
\text { and services } \\
(\% \text { of GDP })^{\star}\end{array}$ & 46.46 & 44.10 & 38.61 & 39.34 & 28.51 & 31.84 & 32.39 & 37.62 & 36.54 \\
\hline
\end{tabular}




\begin{tabular}{|c|c|c|c|c|c|c|c|c|c|}
\hline & 2011 & 2012 & 2013 & 2014 & 2015 & 2016 & 2017 & 2018 & 2019 \\
\hline $\begin{array}{l}\text { HU exports } \\
\text { of goods } \\
\text { and services } \\
\text { (\% of GDP)* }\end{array}$ & 86.58 & 86.32 & 85.58 & 87.41 & 87.97 & 87.15 & 87.14 & 84.93 & 83.32 \\
\hline $\begin{array}{l}\text { KZ HDI } \\
\text { (human de- } \\
\text { velopment } \\
\text { index)** }\end{array}$ & 0.764 & 0.772 & 0.782 & 0.791 & 0.798 & 0.806 & 0.808 & 0.813 & 0.817 \\
\hline HU HDI** & 0.826 & 0.823 & 0.826 & 0.835 & 0.833 & 0.835 & 0.838 & 0.841 & 0.845 \\
\hline 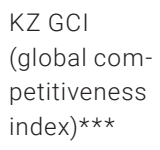 & 4.11 & 4.18 & 4.37 & 4.4 & 4.41 & 4.48 & 61.13 & 61.8 & 62.94 \\
\hline $\mathrm{HU} G \mathrm{Cl} I^{\star \star *}$ & 4.32 & 4.36 & 4.3 & 4.24 & 4.28 & 4.25 & 63.43 & 64.31 & 65.08 \\
\hline
\end{tabular}

In the period studied (2011-2019) the GDP per capita was consistently higher in Hungary than in Kazakhstan. The only exception being 2013 when in Hungary the GDP per capita was lower than in Kazakhstan. This was a protracted consequence of the greater decline in Hungarian GDP growth rate experienced in 2012 due to the drought and the low domestic demand (causing contraction of production in most industries). It was also a consequence of the unfavorable external conditions, such as the European debt management crisis (Eurozone Recession Deepened at End of 2012, 2013). All those aspects together were causing weaker performance of export markets as well (KSH, 2013). Gross National Income (GNI) per capita was also consistently higher in Hungary. In Kazakhstan, it fluctuated more heavily, thus in late 2019 Hungary's GNI was double that of Kazakhstan (World Bank, 2020b).

Annual GDP growth in Kazakhstan was quite outstanding in 2011 (7.4\%) but subsequently experienced a significant crash and fluctuation in the period 2015-2016 before approaching the level of Hungarian growth in 2019. Similarly, like Germany, in 2012, Hungary experienced a severe decline (-1.5\%) and the second slowdown in 2015-2016 before starting to grow again. In 2020, the annual GDP growth rate was $-5 \%$ in Hungary, a bit lower than the $27 \mathrm{EU}$ countries average of $-5.9 \%$ (Eurostat, 2020; World Bank, 2020c) and $-2.6 \%$ in Kazakhstan (World Bank, 2020d), indicating that Kazakhstan had taken the lead in this regard, experiencing a smaller decline. 
The annual industrial growth declined in Kazakhstan in 2015-when the real GDP growth rate was only $0.1 \%-$, while Hungary, in the same year, saw the biggest industrial development (7.69\%). Hungary's industry performed negatively in three consecutive years, 2011-2013, as well as in 2016.

The inflation rate was at its highest peak in Kazakhstan in 2016, reaching $14.54 \%$. The Highest inflation experienced in Hungary was 5.01\% in 2012 (World Bank, 2020b). The lowest inflation experienced in Kazakhstan was $5.12 \%$ and happened in the same year of 2012. Hungary experienced deflation, negative inflation in two consecutive years, in 2014 and 2015 (-0.22\% and -0.06\%) (World Bank, 2020b). Such differences and complementarities in terms of industrial and economic development in the two countries could foster trade between them.

The exports of goods and services in Kazakhstan fluctuated during the examined period and were at their lowest in 2015 (28.51\% of GDP), while the respective exports were at their highest in Hungary in the same year (87.97\% of GDP). Exports were even in the last nine years, with a slight decline in both countries in the past few years. However, Kazakhstan experienced a significant relapse between 2011 and 2019-from 46.46\% to $36.54 \%$ of GDP (World Bank, 2020b). Hungarian exports relative to the size of GDP were consistently double the respective figure for Kazakhstan, meaning that the Hungarian export strategy could probably serve as an example for Kazakhstan.

The human development index (HDI) increased in both countries. The growth was higher in Kazakhstan-from 0.764 to 0.817 , compared to 0.826 to 0.845 in Hungary-and took place more evenly, while in Hungary, it fluctuated in 2012 and 2015. In 2018, the HDI was similar in Kazakhstan and Hungary-0.817 and 0.845, respectively (United Nations Development Programme, 2020).

The unemployment rate in the first quarter of 2020 was similar in the two countries, at 4.35\% in Hungary and 6.05\% in Kazakhstan (Macrotrends, 2021; Statista, 2020). Similarities in terms of human development also offer a stable background for cooperation in the future.

Kazakhstan scored 62.94 points out of 100 , while Hungary scored 65.08 points in the 2019 Global Competitiveness Report published by the World Economic Forum (World Economic Forum, 2020). This means that the two countries are relatively close in terms of their Human Development and Global Competitiveness rankings.

Government debt to GDP was far higher in Hungary, at 80.4\%, in December 2019 than in Kazakhstan, where it was 23.4\% in December 2020 (Trading Economics, 2020a), 
which allows the Kazakh government bigger room for economic and trade maneuvers. However, the macroeconomic differences outlined above could contribute to building of further trade deals based on each country's competitive advantages.

\section{Foreign trade specificities}

International trade plays a significant role in the economy of each country. It allows the specific needs of the population to be met and stimulates the country's internal development (Makhmutova \& Mustafin, 2017). The trade balance in Kazakhstan appears more unstable than that of Hungary (see Figure 1 below).

\section{Figure 1}

Trade Balance in Hungary and Kazakhstan, 1992-2018

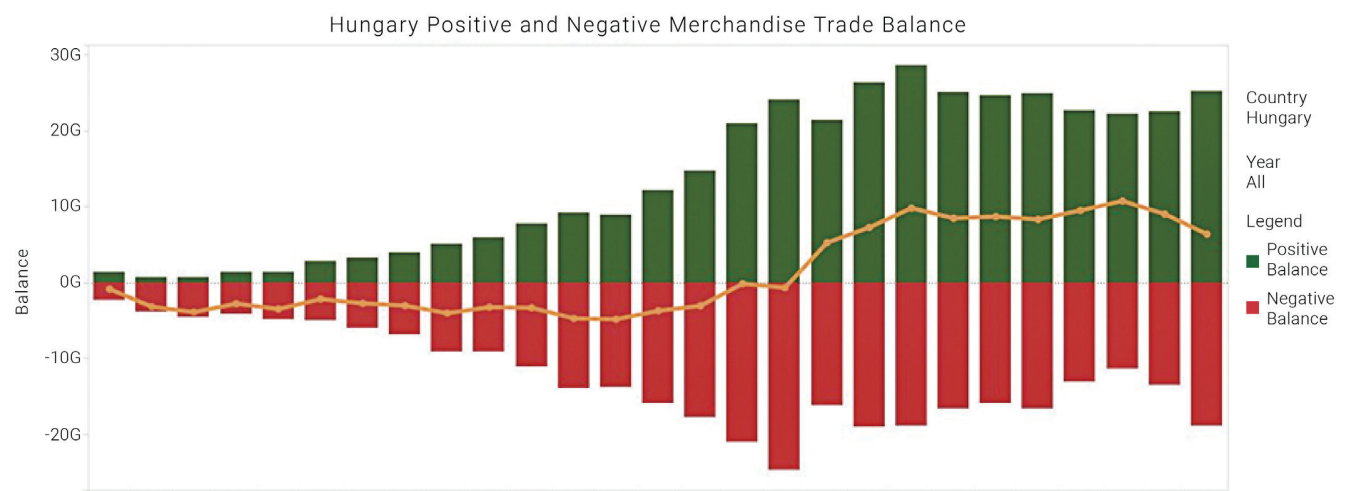

199219931994199519961997199819992000200120022003200420052006200720082009201020112012201320142015201620172018

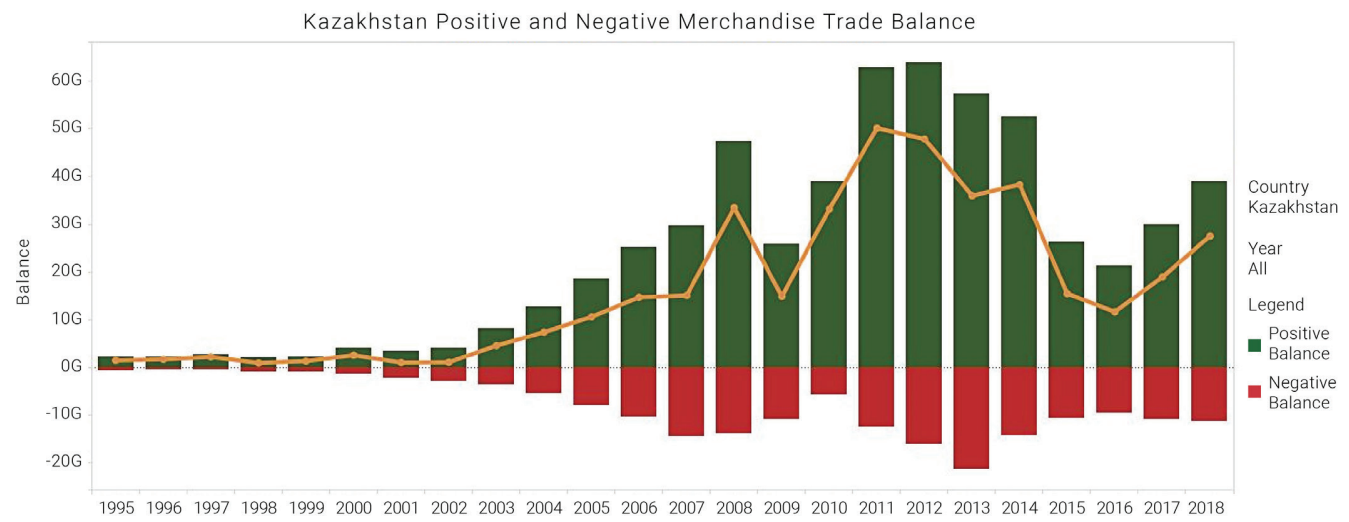

Source: World Bank Positive and Negative Merchandise Trade Balance 
Hungary's main exports include machinery and transportation equipment, consumer goods, agricultural products, chemicals, clothing, textiles, iron and steel, and wine (Trading Economics, 2020b). Kazakhstan's main exports list oil and related products (73\% of total exports), ferrous metals, copper, aluminum, zinc, and uranium (Trading Economics, 2020c).

Hungary trades mainly with EU countries-over 79\%. Germany was the biggest importer of goods from Hungary in 2020 (28\%), followed by Slovakia (5.4\%), Italy (5.2\%), Romania (5.2\%), and various other countries, including Austria, France, Poland, The Czech Republic, and the Netherlands. Hungarian exports to Kazakhstan decreased in value, from around USD 210 million in 2013 to 105 million in 2019 and then increased slightly to USD 165 million by 2020. In 2020, Hungary was exporting mainly pharmaceutical products, miscellaneous chemical products, live animals, machinery, nuclear reactors, boilers to Kazakhstan (Trading Economics, 2020b).

In 2020, Kazakhstan was exporting mainly to Italy (15\%), China (14\%), Russia (9.7\%), the Netherlands (7.6\%), and France (6.3\%), as well as to other countries including, South Korea, Turkey, and Spain. The decline in Kazakh exports to Hungary between 2010 and 2019 was even more significant than the decline in Hungarian exports to Kazakhstan (falling from almost USD 200 million to USD 10 million). In 2020, Kazakhstan exported goods worth USD 10.26 million to Hungary, mainly fish, crustaceans, mollusks, aquatics invertebrates, machinery, nuclear reactors, boilers, Miscellaneous chemical products, iron, and steel (Trading Economics, 2020c).

Foreign direct investment (FDI) increased by 4445.80 USD Million in the fourth quarter of 2020 in Kazakhstan and increased by 1606.50 EUR Million (1911 Million USD) in the fourth quarter of 2020 in Hungary, meaning that Kazakhstan was attracting more than double amount of FDI compared to Hungary (Trading Economics, 2020b).

\section{Economic cooperation features}

The Hungarian and Kazakh governments regard one another as key strategic partners (MKIK, 2020). They signed a new cooperation agreement almost every year-in 1996 on aviation; in 1997 on the avoidance of double taxation; in 1998 on the international carriage of passengers and goods by road; in 1999 on the promotion and mutual protection of investments; in 2008 on economic cooperation between Exim bank and KazAgro; and 2014 on the establishment of a common mutual fund (Külgazdasági és Külügyminisztérium, 2018). Finally, in 2016, executives from Eximbank and KazAgro 
signed an agreement on a joint Kazakh-Hungarian agricultural investment fund. The initial size of the fund was USD 40 million, representing a contribution of USD 20 million each from both Exim Bank and KazAgro (MKIK, 2020). The cooperation between the Hungarian Eximbank and Astana International Financial Center (AIFC) was also developing successfully, the Hungarian Exim Bank opening its representative office in the Astana International Financial Center in 2021 known as Exim Opening Representative Office in Kazakhstan) (Hungary, Kazakhstan 'strategic partners,' 2020).

The Hungarian-Kazakh Intergovernmental Committee for Economic Cooperation has held six meetings to date, in 2008, 2012, and 2016 in Astana-known as Nur-Sultan since 2019-and in 2010, 2014, and 2018 in Budapest (Makhmutova, \& Mustafin, 2017). In April 2019, the Hungarian-Kazakh Strategic Cooperation Meeting took place in Nur-Sultan (MKIK, 2020).

The largest Hungarian investors in Kazakhstan are MOL-the Hungarian Oil Company-a few pharmaceutical companies like Richter Gedeon Nyrt., Egis Zrt., and LAC Holding specialized in professional management services (MKIK, 2020).

In 2020 a project for the construction of a fifth-generation greenhouse complex, the Pickle project, has been implemented in the Aktobe region. In addition to this, Gardens of the East, a $\$ 10$ million project for growing and processing apples was started in the Zhambyl region, using Hungarian technology (Hungary, Kazakhstan 'strategic partners,' 2020).

Since June 2017, there have been direct Wizzair flights between Budapest and NurSultan, which strengthens both business and higher education ties. The flight is popular not only among Kazakh and Hungarian but people from neighboring countries-like Uzbekistan and Russia-also use it (Hungary, Kazakhstan 'strategic partners,' 2020).

The latest development happened on 20 May 2021, when the Hungarian Minister of Agriculture discussed with the Minister of Agriculture in Kazakhstan the further directions for mutual development of partnership and cooperation between the two countries. Aiming to bring together the world-class Hungarian seed sector and the vast production areas of Kazakhstan-more than 21 million hectares (Hungary, Kazakhstan 'strategic partners,' 2020), especially in the field of corn (LAC Holding, 2021). 


\section{The R\&D sectors}

According to some macroeconomic theories-for example Solow's growth modelafter the development of physical capital and the educated labor force, the developed countries could develop further only with new ideas. Thus, the research and development sector has become a priority as it contributes to innovative, cutting-edge economic growth in countries that are unable to grow further by investing more in their capitals (Tabarrok, 2015). This is the case in both Hungary and Kazakhstan, where the emphasis is being given lately to the development of the R\&D sector.

\section{Table 2}

Research and Development (R\&D) Expenditure and Number of Researchers Per Capita in Kazakhstan and Hungary

\begin{tabular}{|c|c|c|c|c|c|c|c|c|}
\hline & 2011 & 2012 & 2013 & 2014 & 2015 & 2016 & 2017 & 2018 \\
\hline $\begin{array}{l}\text { KZ } \\
\text { R\&D expen- } \\
\text { diture (\% of } \\
\text { GDP)* }\end{array}$ & 0.15 & 0.16 & 0.17 & 0.16 & 0.16 & 0.14 & 0.12 & 0.12 \\
\hline $\begin{array}{l}\text { HU } \\
\text { R\&D expen- } \\
\text { diture (\% of } \\
\text { GDP)* }\end{array}$ & 1.18 & 1.26 & 1.38 & 1.35 & 1.36 & 1.20 & 1.34 & 1.55 \\
\hline $\begin{array}{l}\text { KZ } \\
\text { Researchers } \\
\text { in R\&D } \\
\text { (per million } \\
\text { people)* }\end{array}$ & 385.91 & 612.18 & 737.22 & 798.66 & 777.14 & 693.68 & 666.14 & 666.93 \\
\hline $\begin{array}{l}\mathrm{HU} \\
\text { Researchers } \\
\text { in R\&D } \\
\text { (per million } \\
\text { people)* }\end{array}$ & $2,326.16$ & $2,416.47$ & $2,546.08$ & $2,673.43$ & $2,589.09$ & $2,645.75$ & $2,921.53$ & $3,237.70$ \\
\hline
\end{tabular}

Source: Own compilation based on *World Development Indicators

However, it seems that Hungary could afford to spend more on R\&D, thus expenditure on research and development as a percentage of GDP was consistently higher here than in Kazakhstan. The best year in this respect was 2013 in Kazakhstan (0.17\%) and 2018 in Hungary (1.55\%). The lowest rates were in 2017-2018 in Kazakhstan and 2011 in Hungary. The number of researchers per million people was six times higher in Hungary than in Kazakhstan in 2011. This advantage had been reduced to 4.56 times 
higher by 2018 (667 researchers per million), although the difference remained significant. In Kazakhstan, the number of researchers per million people was highest in 2014, at 798.66 researchers per million people, while in Hungary, it was highest in 2018, at 3,237.7 researchers per million people (World Bank, 2020a). This helps explain why Kazakhstan is investing in educational programs such as Bolashak inviting foreign university teachers and researchers to take up temporary posts to develop teaching and research activities at their universities, and endeavoring to adjust to European requirements in this field.

\section{Higher Education Cooperation}

The relationship between the two countries is not based exclusively on economics. Artists, scientists, athletes from the two countries are involved in various cultural and sporting events held in both countries (Hungary, Kazakhstan 'strategic partners,' 2020).

Education is an important element in bilateral cooperation. In Kazakhstan, there are 131 institutes of higher education. 223 academic programs are taught entirely in English at 21 universities. More than 300 programs are run jointly with international institutes of higher education. (Sphere, 2021). In Hungary, there are currently 22 state universities (including universities of applied sciences) and seven non-state universities, five state and four non-state universities of applied sciences, as well as 1 state college and 26 non-state colleges-of which 21 are church-run (Eurydice, 2021).

In 2013, the Ministry of Human Resources in Hungary and the Ministry of Education and Science of the Republic of Kazakhstan signed an agreement on educational and scientific cooperation to develop educational cooperation and further strengthen and expanding relations between the two countries. The agreement initially provided scholarships for 45 Kazakh and Hungarian students per year to participate in undergraduate, master's level, and doctoral studies, although the numbers later increased (Emberi Erőforrások Minisztériuma, 2013). Educational cooperation between the two countries has operated on this legal base ever since.

Since 2018, the development of tourism, energy, and educational projects has been given particular attention (Székely, 2016).

In 2019, new Hungarian-Kazakh cooperation in the field of agricultural research and education was established by the Hungarian National Center for Agricultural Research and Innovation-Research Institute of Agricultural Economics and the Kazakh Agro-technical University (NAIK \& Agroinform, 2019). 
Since 2015 Erasmus+ international credit mobility has been available at Hungarian institutes of higher education through the Erasmus Charter for Higher Education. Kazakhstan belongs to the Development Cooperation Instrument's Central Asia region, with Kyrgyzstan, Tajikistan, Turkmenistan, and Uzbekistan. In 2020, the budget available for this region to support mobility activities with Hungarian institutes of higher education was EUR 118,426. In 2020, applications reached almost five times the budget available for this region; thus, many programs ended up on a waiting list (Tempus Közalapítvány, 2020a).

The KA107 Erasmus+ international mobility program is becoming more and more widespread. According to data from Hungary's Tempus Public Foundation, although the number of Kazakh students coming to study in Hungary rose from 6 to 21 between 2015 and 2019, there were only 6 Hungarian students in 2016 going to study in Kazakhstan (KA107 Erasmus+ International Credit Mobility-Kazakhstan. Tempus Közalapítvány [Tempus Public Foundation], Personal Communication, July 17, 2020).

The student mobility program for internships seems to be unknown, as no one opted for it. While the staff mobility program for educational purposes was more popular among Hungarian staff members, mobility for training purposes get more attention among Kazakh staff members. The duration of mobility among outgoing-that is, Hungarians in Kazakhstan-trainers, 28 people, was the following: 23 people for 5 days, 1 person for 7 days, 2 people for 10 days, and 2 people for 14 days. The duration of mobility among incoming-that is, Kazakhs in Hungary-trainers, 25 people split into days was the following: 17 people for 5 days, 2 people for 6 days, 1 person for 8 days, 1 person for 12 days, and 4 people for 14 days. This indicates that Hungarian teachers prefer shorter stays than their Kazakh counterparts (KA107 Erasmus+ International Credit Mobility-Kazakhstan. Tempus Közalapítvány [Tempus Public Foundation], Personal Communication, July 17, 2020).

The number of mobile teachers and students gradually increased up until 2020, even in the most recent academic year, and against all pandemic circumstances grew further (KA107 Erasmus+ International Credit Mobility-Kazakhstan. Tempus Közalapítvány [Tempus Public Foundation], Personal Communication, July 17, 2020). 


\section{Table 3}

Number of Hungarian and Kazakh Students and Staff Involved in Erasmus Mobility Programs in the Academic Years 2015/16-2020/21

\begin{tabular}{|c|c|c|c|c|c|c|c|}
\hline \multirow[b]{2}{*}{ Study year } & \multicolumn{2}{|c|}{$\begin{array}{l}\text { Student mobility for } \\
\text { study purposes (SMS) }\end{array}$} & \multicolumn{2}{|c|}{$\begin{array}{l}\text { Staff mobility for educa- } \\
\text { tional purposes (STA) }\end{array}$} & \multicolumn{2}{|c|}{$\begin{array}{l}\text { Staff mobility for } \\
\text { training purposes (STT) }\end{array}$} & \multirow[b]{2}{*}{ Total } \\
\hline & Outbound & Inbound* & Outbound & Inbound & Outbound & Inbound & \\
\hline $2015 / 16$ & 0 & 6 & 4 & 4 & 2 & 9 & 25 \\
\hline $2016 / 17$ & 6 & 7 & 5 & 5 & 3 & 2 & 28 \\
\hline $2017 / 18$ & 0 & 6 & 6 & 9 & 5 & 3 & 29 \\
\hline 2018/19 & 0 & 21 & 8 & 6 & 0 & 3 & 38 \\
\hline $2019 / 20$ & 0 & 6 & 5 & 1 & 2 & 1 & 15 \\
\hline $2020 / 21$ & 10 & 4 & 8 & 8 & 0 & 1 & 31 \\
\hline Total & 16 & 50 & 36 & 33 & 12 & 19 & 166 \\
\hline
\end{tabular}

*outbound $=$ Hungarians going to Kazakhstan; inbound = Kazakhs going to Hungary Based on data provided by the Hungarian Tempus Office, 2021

Based on the Higher Education Information System (FIR) module of the National Statistical Data Collection Program (OSAP) in Hungary, there is only one single employee of Kazakh nationality teaching in a Hungarian institute of higher education. The employee concerned had a continuous employment relationship from the autumn semester of the 2017/18 academic year to the spring semester of the 2019/2020 academic year (KA107 Erasmus+ International Credit Mobility-Kazakhstan. Tempus Közalapítvány [Tempus Public Foundation], Personal Communication, July 17, 2020).

It seems that the Stipendium Hungaricum program might be able to attract more students than the Erasmus+ mobility program. However, the Stipendium Hungaricum program is unilateral: only Kazakh students can use it to study in Hungary. The total number of Kazakh students studying in Hungary with government support through the Stipendium Hungaricum has gradually increased, from 51 in 2015/16 to 478 in the $2020 / 2021$ academic year. However, the proportion of foreign students coming from 67 countries has not increased significantly, and it grew from $4.03 \%$ to just $4.75 \%$ in 2019 (Tempus Közalapítvány, 2020b). This suggests that the Hungarian government has expanded the total number of Stipendium Hungaricum grants, not only those awarded to Kazakh students. 


\section{Table 4}

Number and Percentage of Kazakh Students Studying with a Stipendium Hungaricum (SH) Scholarship in Hungary between 2015 and 2019

\begin{tabular}{|c|c|c|c|c|c|c|}
\hline \multirow{2}{*}{$\begin{array}{l}\text { Country of } \\
\text { citizenship }\end{array}$} & \multicolumn{6}{|c|}{ Study year } \\
\hline & $\begin{array}{l}2015 / 16 \\
\text { autumn }\end{array}$ & $\begin{array}{l}2015 / 16 \\
\text { spring }\end{array}$ & $\begin{array}{l}2016 / 17 \\
\text { autumn }\end{array}$ & $\begin{array}{l}\text { 2017/2018 } \\
\text { autumn }\end{array}$ & $\begin{array}{l}\text { 2018/2019 } \\
\text { autumn }\end{array}$ & $\begin{array}{l}\text { 2019/2020 } \\
\text { autumn }\end{array}$ \\
\hline Kazakhstan* & 51 & 51 & 88 & 207 & 333 & 429 \\
\hline $\begin{array}{l}\text { \% of Kazakh } \\
\text { students out } \\
\text { of total SH } \\
\text { students** }\end{array}$ & 4.03 & 3.82 & 3.01 & 4.02 & 7.03 & 4.75 \\
\hline
\end{tabular}

Based on the following: *(Tempus Public Foundation, 2020); **based on (Tempus Public Foundation)

In 2020, more than 600 Kazakh students were studying in Hungary due to the Stipendium Hungaricum program (Hungary, Kazakhstan 'strategic partners,' 2020).

\section{Conclusions and Prospects}

The most surprising finding in this secondary data analysis was that although according to their declarations, the two governments appear to invest a lot of effort into building and strengthening the strategic partnership between the two countries-by means of annual and new economic and trade agreements,- the Hungarian exports to Kazakhstan still have fallen by 50\% between 2013 and 2019, and Kazakh exports declined even more, to 5\% of their previous level, in between 2010 and 2019.

Plenta (2016) comes to similar conclusion regarding the EU countries and Kazakh ties; he states that we can see the difference between declared ambitions and the real situation. The EU strategy through regular meetings between European and Kazakh representatives helps increase contacts at the highest level. "Kazakhstan has increased its ties with Europe. However, apart from political dialogue, I don't think that relations have increased so much" (Plenta, 2016, p. 84).

Further research would be needed to analyze what are the reasons behind this contradiction, why there is this clash between the declared intentions and the real situation regarding the size of the trade and economic cooperation between the two countries. Based on a previous study (Plenta, 2016), we could suppose that the problems are caused by the differences in cooperation with large, "western" enterprises, as small and medium-sized companies in Kazakhstan, which are still in the "Soviet thinking model" 
(Plenta, 2016, p. 88), were marked as not fully reliable. Another problem is unclear and unstable legislation, weak enforcement of the law, and corruption. On paper everything is acceptable, however there are problems with custom services, the rapid legislation changes, and the laws that are not strict in business cooperation, the most significant problem identified was the level of corruption in the country (Plenta, 2016).

Studies have shown that the most promising area for future cooperation between Kazakhstan and Hungary could be the agricultural sector. Hungary, which operates according to the EU standards, has technologies and a qualified workforce for processing agricultural products. Kazakhstan has huge potential for producing environmentally friendly agricultural products. The two countries could cooperate in order to create competitive Kazakh products and bring them to the markets of the Eurasian Economic Union, China, and Central Asian countries (Hungary, Kazakhstan 'strategic partners,' 2020).

Potential business investment areas for Hungarian companies include fruit and vegetable production-greenhouse vegetable production; the planting of apple, cherry, and other orchards-fodder and crop production-maize, corn, sunflowers, sugar, and sorghum-and the food industry (meat processing and the production of dried and canned vegetables and fruits). Other areas include the healthcare industry-for example, the assembly of medical devices and equipment-medical tourism, that is rehabilitation; construction technologies; water industrial technologies-the development of water utilities and wastewater treatment-and waste processing (Külgazdasági és Külügyminisztérium, 2018).

Kazakhstan produces medicines and medical devices, although not in sufficient quantities to meet the needs of its internal market. The Hungarian company Richter Gedeon has thus established a representative office and a joint venture, Egis, while all international pharmaceutical companies that have subsidiaries in Hungary-for example, Sanofi-are also present in Kazakhstan. However, the market is highly regulated, with public procurement carried out by a public body. Thus, market entry is limited in this field. At the same time, Hungarian healthcare equipment and products can be successful in some segments if suppliers ensure the registration of such equipment, which is a process that requires a minimum of 6 months. The COVID-19 epidemic resulted in a significant increase in demand for imported products in the first quarter of 2020; however, this demand may decline due to the expansion or re-profiling of local production. At the same time, the demand for import substitution solutions has increased, which may result in success for Hungarian manufacturers following recovery from the epidemic (Külgazdasági és Külügyminisztérium, 2021). 
The pull sectors will remain industry, construction, and agriculture. It can be assumed that due to a lack of financial resources-and the high cost of credit and funds on the local market-among Kazakh partners, financing will be expected from the Hungarian side. Thus it would be expedient to find out about the available financing and/or risksharing solutions at Eximbank (MKIK, 2020).

In April 2020, the Kazakh government announced an economic protection action plan in Nur-Sultan, due to the spread of the COVID-19 virus and the drastic fall in the price of oil, which is a significant source of revenue for the country. To provide basic food items, the state credit line has to date been raised from KZT 600 million to 1 billion, and the interest rate on this was reduced by between $13 \%$ and $15 \%$. Companies importing agricultural products are no longer subject to VAT. The government has set aside EUR 300 billion for infrastructural development, employing 120,000 people, exclusively Kazakh citizens (Benkő, 2007). There will still be a demand for agricultural technologies, with the increased demand for Hungarian financing (MTI \& Hungary Today, 2020).

State measures to combat the COVID-19-related downturn, which could amount to KZT 5.9 trillion (approximately HUF 5 billion), will prioritize the development of the construction industry, thus offsetting rising unemployment. (Planned projects include housing construction, road construction, and renovation, the construction of the Sary-Arka gas pipeline, the expansion of the Tengiz/Atyrau site, and the completion of the Almaty ring road.) A significant share of the technologies is available, although there is a demand for new technologies, and the production of building materials is constantly expanding. At the same time, considering the development of the exchange rate, the Kazakh partners are very cost-sensitive-for example, in terms of planning, the Hungarian price level can be considered high on the market (Külgazdasági és Külügyminisztérium, 2021).

The Hungarian government and business groups are working on implementing Hungarian projects in the fields of green management, waste management, road construction, and logistics. The initiative to present and promote Hungarian products at the Khorgos International Center of Boundary Cooperation, a special economic zone that includes the Kazakh-Chinese border crossing, could be a big step in bringing Hungarian products to the Kazakh market (MKIK, 2020).

Finally, it gives space for optimism that the exports in both directions started to recover against the difficult pandemic situation in 2020. The Hungarian exports to Kazakhstan increased from 105 million USD in 2019 to 165 million USD in 2020-this stands for 57\% annual growth-and Kazakhstan exports to Hungary from 10 million USD in 2019 to 10.26 in 2020-meaning 2.6\% annual growth. 
The cooperation in the fields of R\&D and higher education evolved linearly and continuously between 2011 and 2020, which gives hope for further developments in this area. Through this cooperation, Hungary could assist Kazakhstan in setting up more international relations in the European region becoming an even more influential country in Central Asia in the areas of economy and education.

\section{References}

A Kormány 197/2008. (VIII. 4.) Korm. Rendelete a Magyar Köztársaság Kormánya és a Kazah Köztársaság Kormánya között a gazdasági együttműködésről szóló megállapodás kötelező hatályának elismerésére adott felhatalmazásról és kihirdetéséről [Agreement between the Government of the Republic of Hungary and the Government of the Republic of Kazakhstan on Economic Cooperation]. (2008). Gazdasági Közlöny, 8, 498-500.

Arunachalam, S., \& Doss, M. J. (2000). Mapping International Collaboration in Science in Asia through Coauthorship Analysis. 79(5), 621-628. https://repository.arizona. edu/handle/10150/106209

Azarian, R. (2011). Potentials and Limitations of Comparative Method in Social Science. International Journal of Humanities and Social Science, 1(4), 113-125.

Bátorfy A. (2019). Magyarország nemzetiségi térképe [Map of Hungarian nationalities]. https://atlo.team/magyarorszagnemzetisegiterkepe/

Benkő, M. (2007). Közép-Ázsiai krónikák a keleti magyarok részvételéről a kazak kánságok megalapításában [Chronicles of Central Asia on the participation of Eastern Hungarians in the founding of the Kazakh khanas]. In J. Gazda \& E. Szabó (Eds.), Kőrösi Csoma Sándor és keleti hagyományaink (pp. 139-151). Kőrösi Csoma Sándor Közművelődési Egyesület.

Bíró, A. Z., Zalán, A., Völgyi, A., \& Pamjav, H. (2009). A Y-chromosomal comparison of the Madjars (Kazakhstan) and the Magyars (Hungary). American Journal of Physical Anthropology, 139(3), 305-310. https://doi.org/10.1002/ajpa.20984

Cohen, A. (2008). Kazakhstan: The Road to Independence. Energy Policy and the Birth of a Nation. Central Asia-Caucasus Institute \& Silk Road Studies Program. https://www. files.ethz.ch/isn/131571/kazakhstanindependence.pdf

Emberi Erőforrások Minisztériuma [Ministry of Human Resources]. (2013, November 19). Magyar-kazah oktatási és tudományos együttmüködési megállapodás [HungarianKazakh education and scientific cooperation agreement]. Felsőoktatásért Felelős Államtitkárság. https://2010-2014.kormany.hu/hu/emberi-eroforrasok-miniszteriuma/ felsooktatasert-felelos-allamtitkarsag/hirek/magyar-kazah-oktatasi-es-tudomanyosegyuttmukodesi-megallapodas

Eurostat. (2020). Real GDP growth rate-Volume [Data set]. https://ec.europa.eu/eurostat/ databrowser/view/tec00115/default/table?lang=en

Eurozone recession deepened at end of 2012. (2013, February 14). BBC News. https:// www.bbc.com/news/business-21455423

Eurydice. (2021, March 31). Types of Higher Education Institutions. Eurydice-European Commission. https://eacea.ec.europa.eu/national-policies/eurydice/hungary/typeshigher-education-institutions_en 
Greene, J. C. (2000). Challenges in practicing deliberative democratic evaluation. New Directions for Evaluation, 2000(85), 13-26. https://doi.org/10.1002/ev.1158 Hungary, Kazakhstan 'strategic partners.' (2020, February 3). The Budapest Times. https:// www.archiv.budapesttimes.hu/2020/02/03/hungary-kazakhstan-strategic-partners

KSH [Hungarian Central Statistical Office]. (2013). Hungary, 2012. https://www.ksh.hu/ docs/hun/xftp/idoszaki/mo/hungary2012.pdf

KSH [Hungarian Central Statistical Office]. (2014). 2011. Évi népszámlálás. 10. Vallás, felekezet. Központi Statisztikai Hivatal. https://www.ksh.hu/docs/hun/xftp/idoszaki/ nepsz2011/nepsz_10_2011.pdf

KSH [Hungarian Central Statistical Office]. (2020). Magyarország népességének száma nemek és életkor szerint, 2020. Január 1. [Population of Hungary by gender and age, 1 January 2020] [Data set]. https://www.ksh.hu/interaktiv/korfak/orszag.html

Külgazdasági és Külügyminisztérium [Ministry of Foreign Affairs and Trade]. (2018). Kazahsztán [Kazakhstan] [PDF slides]. http://exporthungary.gov.hu/download/b/35/ 52000/Kazahszt\%C3\%A1n.pdf

Külgazdasági és Külügyminisztérium [Ministry of Foreign Affairs and Trade]. (2021). Kazahsztán [Kazakhstan]. http://exporthungary.gov.hu/download/3/f1/d2000/ Kazahszt\%C3\%A1n_20210920.pdf

LAC Holding. (2021). Kazakh-Hungarian Cooperation Agreement. http://lac.hu/hu/hirek/ reszletek/1005/kazakh-hungarian-cooperation-agreement

Macrotrends. (2021). Kazakhstan Unemployment Rate 1991-2021 [Data set]. https://www. macrotrends.net/countries/KAZ/kazakhstan/unemployment-rate

Magyar Kereskedelmi és Iparkamara (MKIK) [Hungarian Chamber of Commerce and Industry]. (2020). Piaci útmutató a Kazah Köztársaságról [Market guide for the Republic of Kazakhstan]. https://mkik.hu/download/207/kazah-koeztarsasag

Makhmutova, D. I., \& Mustafin, A. N. (2017). Impact of International Trade on Economic Growth. International Journal of Scientific Study, 5(6), 140-144. https://www.ijss-sn. com/uploads/2/0/1/5/20153321/ijss-iran_sep_17_benson_oa29.pdf

MTI \& Hungary Today. (2020, May 6). Coronavirus: Finance Ministry Sees 3 pc GDP Contraction in 2020. Hungary Today. https://hungarytoday.hu/coronavirus-financeministry-sees-3-pc-gdp-contraction-in-2020/

NAIK \& Agroinform. (2019, April 30). Magyar-kazah együttmüködés az agrárkutatásban és -oktatásban. https://www.agroinform.hu/gazdasag/magyar-kazah-egyuttmukodesaz-agrarkutatasban-es-oktatasban-39935-001

Nemzeti fejlesztés 2030 [National Development 2030]. (2014). Magyar Közlöny, 1, 10-298. http://www.kozlonyok.hu/nkonline/MKPDF/hiteles/MK14001.pdf

Parliament Resolution No. 1/2014. (I. 3.) OGY National Development 2030-National Development and Territorial Development Concept [English translation of the "Nemzeti fejlesztés 2030" document, published as article in the "Magyar Közlöny" journal, 2014/1, pp. 10-298]. (2014). https://regionalispolitika.kormany.hu/download/b/c9/ e0000/OFTK_vegleges_EN.pdf

Plenta, P. (2016). The European Two-Level Game in Central Asia: Visegrad Countries and Kazakhstan. Asian International Studies Review, 17(2), 79-99. https://papers.ssrn. com/abstract $=3366941$

PWC. (2021a, June 30). Hungary-Individual-Income determination. PWC Worldwide Tax Summaries Online. https://taxsummaries.pwc.com/hungary/individual/incomedetermination 
PWC. (2021b, July 23). Kazakhstan-Individual-Income determination. PWC Worldwide Tax Summaries Online. https://taxsummaries.pwc.com/kazakhstan/individual/ income-determination

SPHERE. (2021). Higher education in Kazakhstan. Support and Promotion for Higher Education Reform Experts. https://supporthere.org/page/higher-education-kazakhstan

Statista. (2020). Hungary: Unemployment rate from 1991 to 2020 [Data set]. https://www. statista.com/statistics/339859/unemployment-rate-in-hungary/

Székely, T. (2016, June 19). On This Day-In 1991 Soviet Troops Finally Left Hungary After Four Decades of Occupation. Hungary Today. https://hungarytoday.hu/day-1991-soviettroops-finally-left-hungary-four-decades-occupation-video-59830/

Tabarrok, A. (2015). Introduction to the Solow Model. Marginal Revolution University. https://mru.org/courses/principles-economics-macroeconomics/solow-modeleconomic-growth

Tar, G., \& Ujvári, M. (2019). Kazahsztán országinformáció [Kazakhstan country information] [PDF slides]. Külgazdasági és Külügyminisztérium [Ministry of Foreign Affairs and Trade Hungary]. http://exporthungary.gov.hu/download/b/35/52000/ Kazahszt\%C3\%A1n.pdf

Tempus Közalapítvány [Tempus Public Foundation]. (2020a). Nemzetközi kreditmobilitás. 2020. Évi pályázati tudnivalók [International credit mobility. 2020 year application info]. https://tka.hu/palyazatok/7619/statisztikak

Tempus Közalapítvány [Tempus Public Foundation]. (2020b). Stipendium Hungaricum jelentkezői és hallgatói adatok [Stipendium Hungaricum candidates and students data] [Data set]. https://tka.hu/palyazatok/7619/statisztikak

Trading Economics. (2020a). Country List Government Debt to GDP [Data set]. https:// tradingeconomics.com/country-list/government-debt-to-gdp

Trading Economics. (2020b). Hungary Exports [Data set]. https://tradingeconomics.com/ hungary/exports

Trading Economics. (2020c). Kazakhstan Exports [Data set]. https://tradingeconomics. com/kazakhstan/exports

Trading Economics. (2021a). Kazahsztán-Személyi jövedelemadó mértéke [KazakhstanPersonal income tax rate] [Data set]. https://hu.tradingeconomics.com/kazakhstan/ personal-income-tax-rate

Trading Economics. (2021b). Magyarország-Személyi jövedelemadó mértéke [HungaryPersonal income tax rate] [Data set]. https://hu.tradingeconomics.com/hungary/ personal-income-tax-rate

United Nations Development Programme. (2020). Human Development Data Center, Human Development Reports [Data set]. http://hdr.undp.org/en/data

World Bank. (1999). Privatization of the power and natural gas industries in Hungary and Kazakhstan. https://doi.org/10.1596/0-8213-4483-8

World Bank. (2020a). DataBank: Researchers in R\&D (per million people) [Data set]. https://data.worldbank.org/indicator/SP.POP.SCIE.RD.P6

World Bank. (2020b). DataBank: World Development Indicators [Data set]. https://databank.worldbank.org/source/world-development-indicators

World Bank. (2020c). DataBank: World Development Indicators. GDP growth (annual \%)Hungary [Data set]. https://data.worldbank.org/indicator/NY.GDP.MKTP.KD.ZG? locations $=\mathrm{HU}$ 
World Bank. (2020d). DataBank: World Development Indicators. GDP growth (annual \%)Kazakhstan [Data set]. https://data.worldbank.org/indicator/NY.GDP.MKTP.KD.ZG? locations $=K Z$

World Bank Group. (2020a). Doing Business 2020. Hungary. https://www.doingbusiness. org/content/dam/doingBusiness/country/h/hungary/HUN.pdf

World Bank Group. (2020b). Doing Business 2020. Kazakhstan. https://www.doingbusiness.org/content/dam/doingBusiness/country/k/kazakhstan/KAZ.pdf

World Economic Forum. (2020). Global Competitiveness Report Special Edition 2020: How Countries are Performing on the Road to Recovery. https://www3. weforum.org/ docs/WEF_TheGlobalCompetitivenessReport2020.pdf 